\title{
Professional ethics: know-how, deontological code and legality
}

\author{
Gian Vito Graziano
}

President, National Council of Geologists, Rome, Italy

\author{
Article history \\ Received January 12, 2012; accepted February 29, 2012. \\ Subject classification: \\ Deontological code, Legality, Geoethics, Professional association, Geologists.
}

\begin{abstract}
The greatest sensitivity and attention to the geoenvironmental problematic underline the urgency to face some matters with new awareness and responsibility, like the management of the territory, the exploitation of the georesources, the energy problem, and the defense against natural risks. The civil community asks for ready and exhaustive answers. The technical-scientific competence of the geologist, linked with the shared deontological practice with respect to the normative in force, can give trust back to the citizens, and support to the political decisoris, the safety and the raising of our professionalism. The Italian territory is a great economic, social and cultural resource that must be defended and valued through the contribution of geologists. New strategies, spheres of action, and operational tools are needed. The National Council of Geologists in Italy is working in this direction.
\end{abstract}

\section{Introduction}

For some time, professionals, and also lecturers and researchers, have been asked more and more insistently to take up a social role to serve the community.

Geologists have been credited with a social responsibility aimed at "encouraging critical analysis of natural resources exploitation, promoting the value and the safeguarding of the geosphere, communicating information regarding natural hazards in a fair way, and engaging society with the idea of a shared geological heritage that can contribute to the social construction of knowledge" [Geoethics Manifesto 2011].

The social construction of knowledge is an important challenge, and geologists have to make a contribution; however, this requires cultural and social renewal of the Earth sciences and of all of its 'souls', who are perhaps not always fully aware of the significant social effects of their work.

\section{The role of professional associations}

What is the role of professional associations in the light of this hoped-for ethical renewal? Their role is certainly strategic from several aspects: from the spreading of knowledge to all groups of society, to scientific and technical train- ing of the members of the associations, to prepare them for the various requests coming from the community. However, this is totally marginal for matters regarding the often outdated regulations of professional associations, and their institutional roles. It clearly appears that there is the need to reform the professional associations in Italy, possibly with modern, incisive, coherent and shared law reform.

According to their current structure, professional associations are based on two fundamental pillars: deontology and the social role of the profession. The concept of deontology needs to be the focus of the discussion, because as explained later, it should be extended in the current codes to include the foundational principles of legality, which are often omitted. Indeed, even after the Italian Government reforms (called the Bersani reforms), the codes still refer to the noble images of 'ethics' and 'decency' of the profession as they are intended in the Italian Civil Code, but only in considering their application to professional performance, and not to the conduct of the body's members.

In this context, an active role that has yet to be explicitly indicated will also be played by actions against the spread of the criminal system. The dangers of organized crime have often been, and still are, a cause for concern to professional associations, in terms of the involvement of some of their members. For example, in recent times, cases of complicity between members of professional associations and organized crime have been documented not only in southern Italy, where organized crime has a major influence on public life, but also in Milan and Turin (in northern Italy), where the mafia system is expanding dangerously.

As every social actor has the duty to take on an active role against this phenomenon, professional associations cannot shirk their responsibility. Cultural and anti-racket associations, citizens, and others have started to put pressure on the boards of professional associations, which are not always watchful on these issues, to push for greater attention to be paid to the activities and to the conduct of their members, especially, but not only, when their members are under investigation. 
It needs to be asked in the first place: "How did the legislator want to make professional associations vouch for the correct and proper work and conduct of their members?"

To answer questions on this point, some professional associations have officially stated that "the body's board cannot take disciplinary measures on a member investigated for a criminal offence; thus even regarding the mafia, independent of the final outcomes of the criminal case, because it is forbidden by legislation and by numerous Court of Cassation judgments".

It is not quite like this, although it is evident that the issue poses some serious interpretational problems. It is then worthwhile to examine how the activities of the associations are regulated, starting from the institutional law (Italian Law, n. 112, dt 1963) of the Ordine dei Geologi (Italian Order of Professional Geologists), which, being more recent with respect to other professional associations, borrows some of the principal regulatory aspects from earlier institutional laws.

Law Article 5, entitled Prerequisites to become a member, states that to become a member of a professional association there is the need to be an Italian citizen with civil rights, to have irreprehensible moral conduct, to be qualified to carry out the profession, and to be resident in Italy. The legislator thus emphasizes that irreprehensible moral conduct is an essential pre-requisite to become a member of this professional association. Therefore, if the member does not maintain his or her moral conduct in the profession, the professional association is entitled to take disciplinary measures, even resorting to expulsion from the association.

This topic raises another issue regarding the link between judgements made by professional associations and official court sentences. It is not clear whether the disciplinary measures taken by a professional association in the case of a severe criminal or administrative offence committed by one of its members are to be considered as a judgement dependent on a possible parallel criminal trial, or as an autonomous judgement regardless of any court ruling.

The 'Execution Regulations' for Law n. 112 dt 1963 are not helpful in the answering of this question. Law Article 6 states that the expulsion of a chartered member can occur if the member renounces his or her membership, if there is an issue of incompatibility, or if the member does not meet one of the prerequisites of Law Article 5 any longer, as either the Italian citizenship or residence. Moral conduct is effectively excluded from the possible reasons that can be used to justify expulsion from a professional association.

The difficulty encountered by professional associations in dealing with this issue is confirmed by Law article 14 , related to the subsequent integrative regulations regarding the application of Law n. $112 \mathrm{dt}$ 1963, where it is specified that "other than the cases of expulsion from a professional association provided for in the Criminal Code, the expulsion from an association is approved if: (a) an arrest warrant is issued for a member; (b) the member has not paid the professional association dues... The expulsion is legitimate if the chartered member, with the final judgement, has been condemned to incarceration for not less than two years for a nonculpable offence... The expelled member can ask for re-admission if: (a) he or she has been rehabilitated according to the Criminal Code regulations; (b) two years have elapsed since the date of expulsion".

Thus, it is evident that although irreprehensible moral conduct is expressed as a prerequisite for admission, it is not considered in cases of expulsion.

Piero Grasso, Director of the Direzione Nazionale Antimafia (National Anti-Mafia Office) of Italy, has often reminded professional associations of their duty of carrying out their task as guarantors of the professional conduct of their members. He is effectively upholding the principle of social responsibility as it applies to professionals, a principle that is more relevant than the responsibility of the common citizen.

Professionals often provide advice to mafiosi (members of the mafia), advising them on money laundering and even on the subsequent management and investing of the laundered money. The problem of professionals who are found to be in collusion with organized crime has not been addressed; indeed, many doctors, lawyers, engineers, architects and geologists who have been put on trial are still chartered members of their respective professional associations; sometimes also even if they have been condemned for a criminal offence.

\section{Conclusions}

How can we not respond to Piero Grasso's appeal, which is also an appeal by civil society to chartered professionals?

Given the lack of regulations and of reforms, which would allow professional associations to take measures against their members without the fear of being, paradoxically, charged for not respecting regulations, the only way forward is civil courage. This thus departs from the limited view of institutional regulations, and expands upon the meaning of guarantor by giving professional associations a function that the legislator has not clearly established. By doing so, professional associations can fulfill the social role to which they aspire, and they can also be trusted more by civil society, which often sees professional associations just as corporations. This problem is felt to be a major issue, as shown, for instance, by the subscription of many professional association legality protocols, or by the session dedicated to education and legality by the Sicilian geologists at their last congress.

The first example of courage that I mentioned ear- 


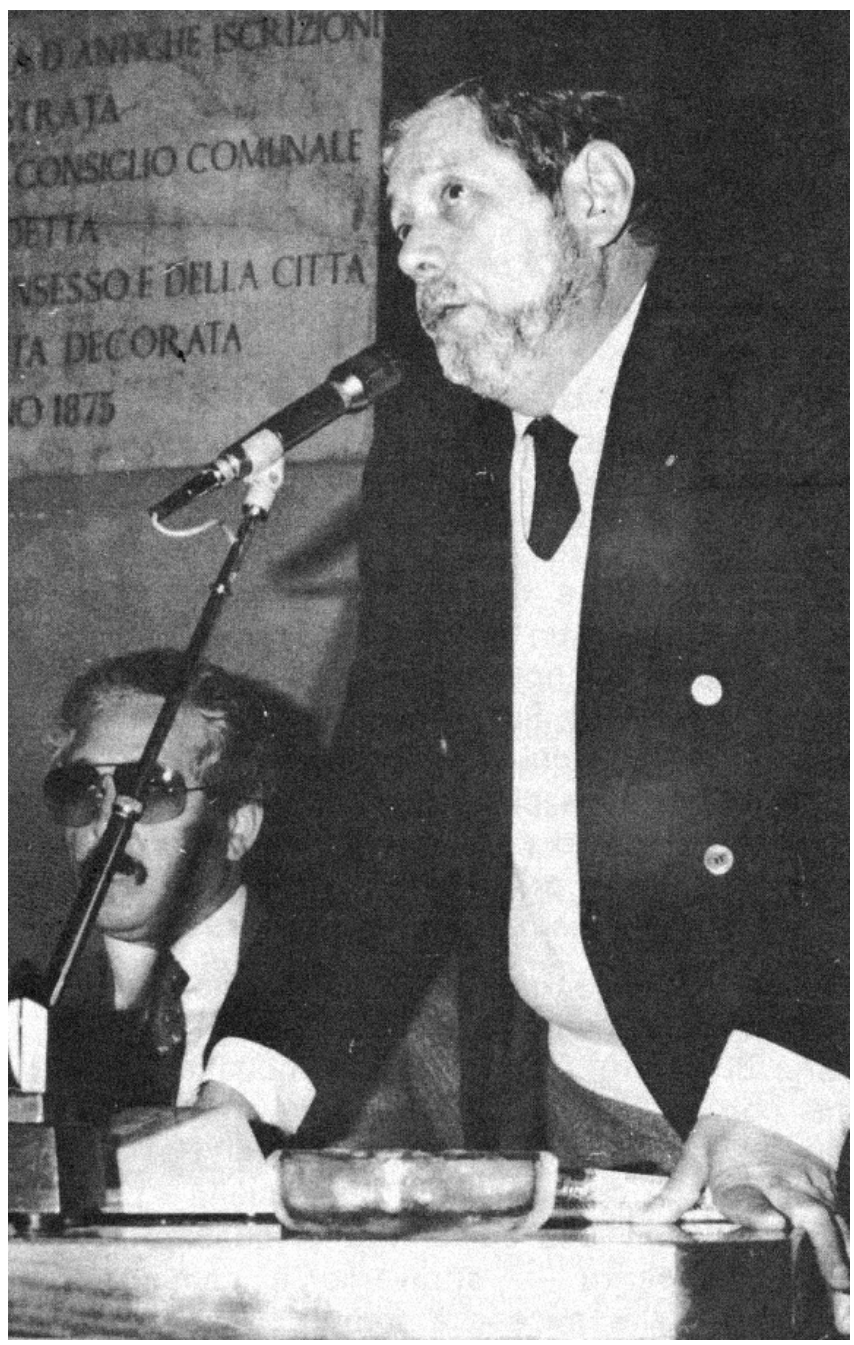

Figure 1. Prof. Giaccone, a doctor killed in 1982 for having done his duty, without yielding to the demands of the mafia.

lier comes from Sicily, from the Institution of Engineers, which expelled a chartered member because he acknowledged that he had been paying protection money to a local mafia gang to safeguard his activities. The decision of the Institution of Engineers was based on the immorality of the member's conduct, and it set an unfortunately isolated precedent, especially because the decision was taken unanimously by the Institution Board, even though the final judgement, which condemned the engineer to 15 years of incarceration, had yet to be proclaimed. The National Council of Engineers re-affirmed that disciplinary measures are autonomous and independent, and confirmed the expulsion decided by the local council because of the serious deontological infringement.

If on the one hand civil courage appears to be the only way forward, on the other hand, there still remains a call for reform of chartered professions that will give a guarantor role to professional associations by extending the deontological precepts. In the meantime it will be worth introducing stricter ethical rules in the deontological codes that are going to be revisited due to the new economic measures.
This is not an overwhelming task. We could start from the Manifesto of the Paolo Giaccone Professional Committee. Paolo Giaccone (Figure 1) was a doctor who was killed in 1982 by the mafia just because he was honestly fulfilling his duties, without giving way to requests from the mafia. The Manifesto puts together a network of hopeful and honest professionals from all around Italy, who pledge "to work bearing in mind society's interests and the profession's social role, and not to work against society's welfare or in a way deleterious to human safety, freedom and dignity" (point 1 of the Manifesto). With their attestation and their personal commitment, these professionals want to put forward a basic concept that is the duty of every citizen: to carry out one's profession with the constant inspiration of achieving that social role that serves the community and that gives one dignity, authoritativeness and civil responsibility.

\section{References}

Geoethics Manifesto (2011). Presented by S. Peppoloni and G. Di Capua at the 8th Italian Forum of Earth Sciences, Turin.

Codice Civile Italiano (Italian Civil Code), Istituto Poligrafico e Zecca dello Stato (IPZS).

Gazzetta Italiana n. 79, 4 Aprile 1942 (Italian Gazette n. 79, 4th April 1942); www.ipzs.it.

Legge n.112 del 1964: "Tutela del titolo e della professione di geologo" (Italian Law n. 112 dt 1964: "Protection of the geologist's title and profession").

\section{Websites}

Comitato dei Professionisti Liberi (Italian Free Professionals Committe): www.professionistiliberi.org.

Consiglio Nazionale dei Geologi (National Council of Geologists of Italy): www.cngeologi.it.

Corresponding author: Gian Vito Graziano,

Consiglio Nazionale dei Geologi (National Council of Geologists), Rome, Italy; email: segreteria@cngeologi.it.

C 2012 by the Istituto Nazionale di Geofisica e Vulcanologia. All rights reserved. 